\title{
MOTIVATION-STIMULATION FUNCTION OF WEB PAGES FOR EDUCATION
}

\section{Jan KUBRICKÝ - Karel NEUMANN}

\begin{abstract}
The paper deals the motivaton-stimulation function of web pages for education and is supplemented with the findings and conclusions of a questionmaire investigation in the mentioned area at a Secondary vocational school of Machinery.
\end{abstract}

Keywords: web pages for education, ICT teaching aids, ICT kompetence.

\section{MOTIVAČNÉ-STIMULAČNÍ FUNKCE VÝUKOVÝCH WWW STRÁNEK}

Resumé: Př́spěvek se zabývá motivačně-stimulačni funkcí výukových www stránek, a je doplněn o zjištěni a závěry dotazníkového šetřeni v uvedené problematice na Střední průmyslové škole strojnické.

Klíčová slova: výukové www stránky, technický výukový prostředek, ICT kompetence.

\section{Úvod}

Pozici internetu ve vzdělávání není možno vzhledem k objemnosti a množství služeb daného média přsesně ohraničit. Lze ovšem konstatovat, že prostředky podporované službami internetu je možno do vzdělávání cílevědomě zařadit, a realizovat $\mathrm{s}$ jejich úplnou či částečnou podporou předem zamýšlené činnosti pro plnění didaktických účelů. Chápeme tím naprríklad vytvoření a užití výukových www stránek, jako didaktického média, které prostřednictvím služby www smysluplně využíváme $\mathrm{k}$ edukaci.

Vzhledem ke stále větší aplikovatelnosti výukových www stránek, spočívající především vširoké miŕre možností prezence multimediálních prvků, interaktivního charakteru a snadné, dostupné a málo nákladné aktualizaci, získávají své pevné místo také na ZŠ a SS̆. Přihlédneme-li k mnoha skutečnostem majícím vztah k odborným dovednostem učitelů, technickému zázemí, charakteru vzdělávacích oblastí a dalších, můžeme tvrdit, že využití výukových www stránek je v současnosti častější na SŠ, a proto se dále více zaměříme na ně.

\section{ICT kompetence učitele}

ICT kompetence učitele patří do skupiny kompetencí s největší mírou progrese. Učitelé, zejména technických a informatických předmětů, by chtěli dosahovat nejvyšší možné stanovené úrovně v nakládání s prostř̌edky ICT. To znamená aktivně využívali technologie pro tvorbu a užití vlastních výukových aplikací.
A není tomu tak jen na SS̆, jak už dokazuje provedené šetření Výzkum informační výchovy na základních školách (1).

I z hlediska současné požadované úrovně aplikace ICT do výuky, by učitelé měli být schopni minimálně využívat dostupné technologie, konkrétně být schopni využít například výukových www stránek, popřípadě provádět jejich drobné úpravy atp. Můžeme tak zařadit toto moderní edukační médium do výuky, a patřičně analyzovat jeho úlohu v rámci vzdělávání žáků v nejrůznějších situacích.

\section{Úloha a funkce výukových www stránek}

Výukové www stránky považujeme stále za nové a málo prozkoumané edukační médium. Jejich úlohu nemůžeme specifikovat obecně. Vždy je primárně nezbytné určit účel jejich užití. Jinou úlohu budou plnit výukové www stránky určené pro vizuální podporu přednášené látky, např. prezence obrázků nebo audiovizuálních nahrávek, jinou úlohu nebo úlohu značně rozšířenou budou plnit komplexní výukové stránky určené pro opakování látky nebo samostudium. Jak navíc upozorn̆uje J. Procházka (2), za výukové www stránky můžeme považovat pouze takové, které byly př́mo vytvořeny pro vzdělávací účely.

Do systému edukačního procesu řadíme výukové www stránky jako učební pomůcku použitelnou jen ve spojení s určitou didaktickou technikou. Takovéto spojení označujeme dle V. Rambouska (3) jako ,technický výukový prostředek“. Do stejné skupiny řadíme např. výukové programy (4) (5). Technický výukový 
prostředek musí obecně plnit určité funkce. Mezi základní patř́i funkce motivačněstimulační (3). Můžeme tedy konstatovat, že výukové www stránky by měly podněcovat zájem žáků o studium, a to jak v př́ípadě výuky ve škole, tak při domácím studiu, pakliže jejich úloha spadá též pro podporu domácí prŕípravy žáků. Hovoříme o implementaci ICT kompetencí do výukových aktivit. To v konečném důsledku znamená zvyšování informační gramotnosti žáka a zvýšení zájmu o studium, jak předpokládáme $\mathrm{z}$ motivačněstimulační funkce technického výukového prostředku.

\section{Výukové www stránky a zájem žáků o studium}

Motivace pro níže uvedené dotazníkové šetření zkoumající vliv výukových www stránek na zájem žáka Střední průmyslové školy strojnické (dále jen SPŠS) o studium daného předmětu, vyplývá proto $\mathrm{v}$ ověření motivačně-stimulační funkce technického výukového prostředku $\mathrm{z}$ pohledu samotného žáka. Dalším cílem šetření bylo zjištění, zda výukové www stránky, které se již po určitou dobu bez známých problémů na SPŠS užívají, podněcují žákủv zájem pro domácí př́ípravu, resp. samostudium.
Dotazníkové šetření

Na uvedené škole jsme předložili celkem 100 anonymních dotazníků žákům 2., 3. a 4. ročníků. Návratnost byla $100 \%, \mathrm{z}$ toho 9 dotazníků bylo vyřazeno, ve všech případech pro nesprávné pochopení pojmu výuková www stránka. Výsledky jsme pro jednoduchou představu čtenářům tohoto př́spěvku zpracovali do histogramů četností.

V dotazníku jsme použili polytomické položky s výběrem odpovědí (6):

Otázka:

$A$ ano

$B$ spiše ano

C někdy ano, někdy ne

D spiše ne

Ene

V hlavním bodě šetření bylo našim cílem prostřednictvím dotazníku prozkoumat, zda kvalitní výukové www stránky užívané na konkrétní škole pro podporu výuky při vyučování, plní funkci, která je nezbytnou součástí pro účelné užití technického výukového prostředku.

Zvyšuje se Váš zájem o studium předmět,

když máte možnost využivat výukové www stránky?

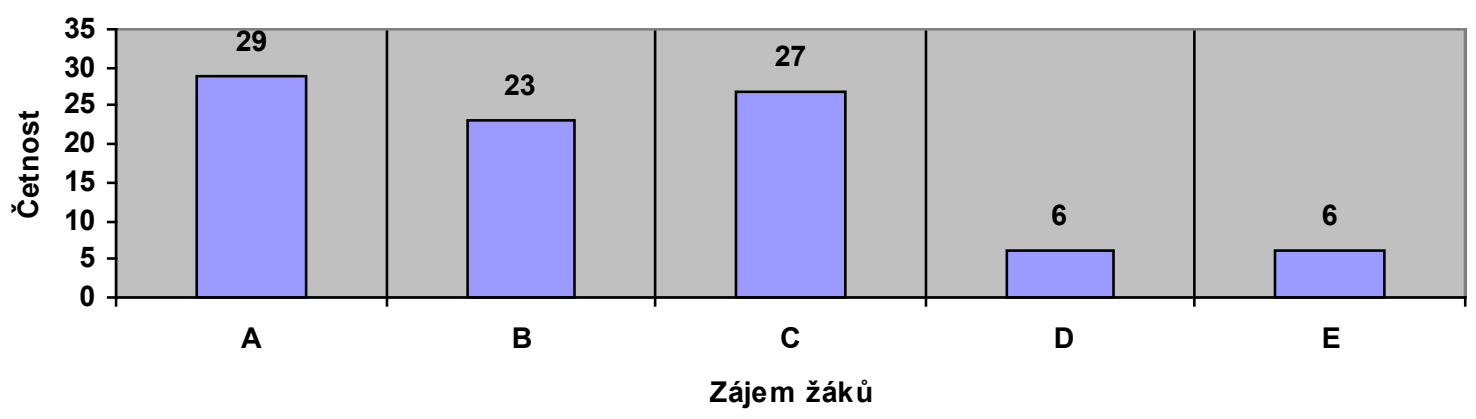

Graf č. 1: Zájem žáků o studium předmètu s výukovými www stránkami.

Výsledky šetření nás $\mathrm{v}$ tomto bodě nikterak nepřkvapily. Už při př́ímém pozorování výuky jsme dospěli k závěru, že žáci ve většině prŕpadů pracují $\mathrm{v}$ předmětech $\mathrm{s}$ výukovými www stránkami se zvýšeným zájmem a aktivněji se zapojují do výuky.

Relativně vysoký počet odpovědí někdy ano, někdy ne interpretujeme dle dalších závěrů z doplňkových položek dotazníkového šetření a následné diskuze ve skutečnosti, že žáci na SPŠS upřednostňují uživání výukových www stránek $\mathrm{v}$ předmětech technického zaměření, před užitím $\mathrm{v}$ předmětech humanitního zaměření.

V druhém bodě šetření jsme žákům předložili následující otázku: 
Uživáte výukové www stránky vdomáci napríkladpři samostudiu? př́pravě i mimo plněni školnich povinností,

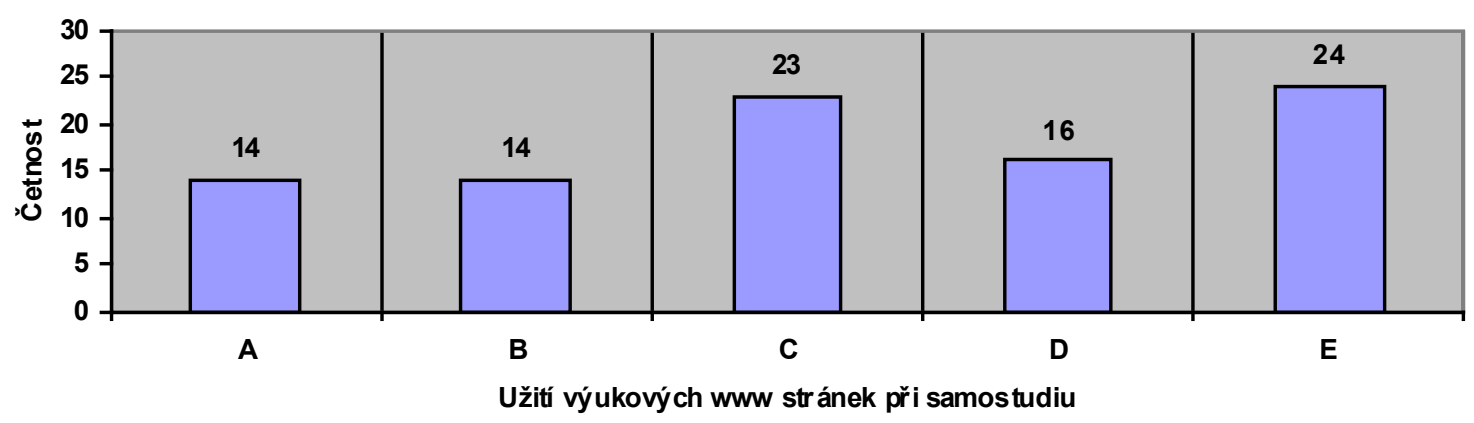

Graf č.2: Užití výukových www stránek při samostudiu.

Motivace žáků voblasti domácí př́ípravy např. formou samostudia je záležitostí silně individuální a není proto možné vyloučit další jevy a skutečnosti, které žáka ovlivňují. Abychom ohraničili výukové www stránky jako relativně jediný podmět vnější motivace žáka při samostudiu, zaměřili jsme se na souvislosti, které je staví do pozice určité moderní formy klasické učebnice.

Považujete výukové www stránky za rovnocennou učebni pomi̊cku vporovnání $s$ učebnicemi?

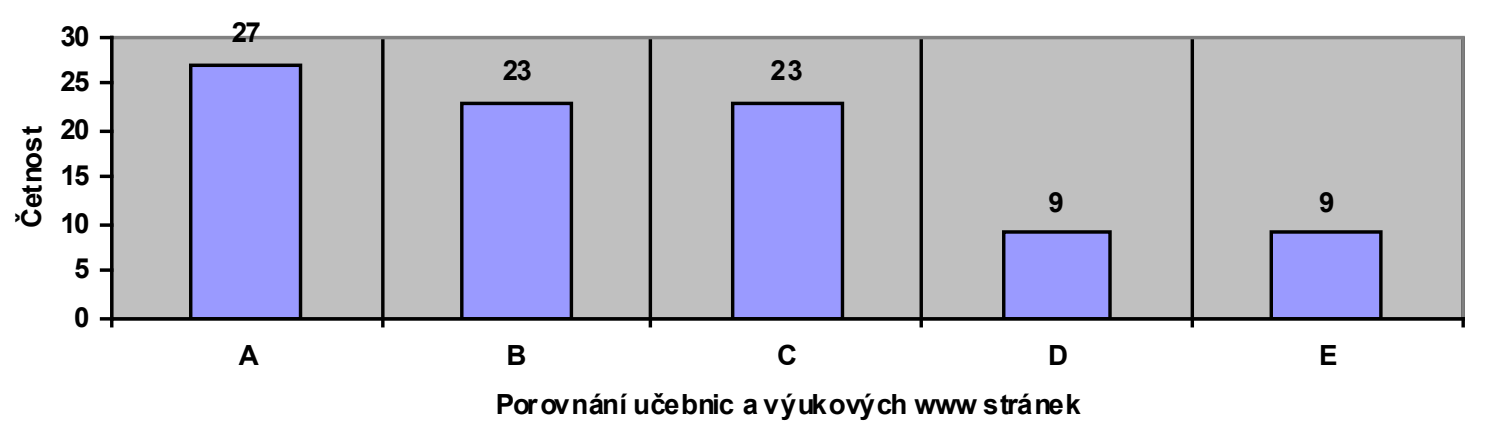

Graf č.3: Porovnání učebnic a výukových www stránek.

Ve výsledcích se opět odráží skutečnost, v níž žáci upřednostňují výukové www stránky $\mathrm{v}$ předmětech technického zaměření. Díky zjištěným výsledkům kombinace předchozích dvou otázek konstatujeme, že výukové www stránky užívané v současné době na SPŠS nemají podstatný vliv na zvýšení motivace pro samostatnou domácí př́ípravu žáků, stejně jako tomu není např́íklad u učebnic. Usuzujeme tak dále $\mathrm{z}$ diskuze, která $\mathrm{s}$ žáky proběhla ihned po provedení dotazníkového šetření. Zajímavostí je, že žáci by současné výukové www stránky více obohatili o možnosti interaktivní komunikace a větší integrací řešené problematiky do problémů běžného života.

\section{Shrnutí výsledků}

Provedené dotazníkové šetření na SPŠS v Olomouci mělo za cíl, lokalizovat pozici výukových www stránek v zájmu žáků o studium prostřednictvím moderního technického výukového prostředku. Zjištěných výsledků bude dále použito pro rozvoj, celkový př́nos a implementaci technologií, které dle našeho soudu a zjištěných závěrů podporují celkový zájem žáka o studium daného předmětu. Dále jsme více porozuměli představám žáků o ideálních výukových www stránkách, a necháme se jimi do budoucna jistě inspirovat.

Specifika středních průmyslových škol do značné míry neumožňují aplikovat dosažených závěrů pro jiné vzdělávací ústavy. Nicméně $\mathrm{v}$ rámci technicky zaměřených škol můžeme 
konstatovat, že užití výukových www stránek zejména $\mathrm{v}$ předmětech technického zaměření zvyšuje stimulaci žáků ke studiu, zejména prostřednictvím zvýšené názornosti.

Závěr

Dle mnohých výzkumných šetření zájem žáků o studium v ČR stále více klesá. Paralelně s tím by se dalo usuzovat na upadající kvalitu vzdělávacích ústavů. Učitelé na všech typech škol se snaží na tuto ne př́liš lichotivou skutečnost reagovat kupř́kladu tak, že zařazují do výukových aktivit moderní vyučovací techniky a $\mathrm{k}$ jejich podpoře užívají různých druhů didaktických výukových prostředků. Výukové programy, výukové www stránky, didaktické hry aj. Do budoucna možná tyto prostředky ve velké míře nahradí klasické vyučovací pomůcky. Nezapomínejme proto na jejich důležitou motivačně-stimulační funkci, která je jedním ze základních předpokladů pro zkvalitnění současného vzdělávání.

\section{Literatura}

(1) RAMBOUSEK, V. a kol. Výzkum informační výchovy na základnich školách. 1. vyd. Plzeň : Koniáš, 2007. ISBN 80-86948-102.

(2) PROCHÁZKA, J. Výukové www stránky jako prostředek edukace. In Vzdělávání pro život v informační společnosti I. 1.vyd. Praha : PdF UK, 2005, s. 117-158. ISBN 80-7290-1982.
(3) RAMBOUSEK, V. a kol. Technické výukové prostředky. 1. vyd. Praha : SPN, 1989. (4) KALHOUS, Z., OBST, O. Didaktika sekundární školy. 1. vyd. Olomouc : UPOL, 2003. ISBN 80-244-0599-7.

(5) DOSTÁL, J. Učební pomůcky a zásada názornosti. 1. vyd. Olomouc : Votobia, 2008. 40 s. ISBN 978-80-7220-310-9. On-line na http://sites.google.com/site/dos003.

(6) CHRÁSKA, M. Metody pedagogického výzkumu. 1. vyd. Praha : Grada Publishnig, 2007. ISBN 978-80-247-1369-4.

\section{Jan Kubrický, Mgr.}

Katedra technické a informační výchovy

Pedagogická fakulta UP

Žižkovo nám. 5

77140 Olomouc

Tel. č. 068/585635819

E-mail: jankubricky@seznam.cz

http://www.kteiv.upol.cz

Karel Neumann, Mgr.

Katedra technické a informační výchovy

Pedagogická fakulta UP

Žižkovo nám. 5

77140 Olomouc

Tel. č. 068/585635813

E-mail: karel.neumann@post.cz

http://www.kteiv.upol.cz 